\title{
Human Parainfluenza Virus 4
}

National Cancer Institute

\section{Source}

National Cancer Institute. Human Parainfluenza Virus 4. NCI Thesaurus. Code C112318.

The serotype labeled 4 of the viral species Human parainfluenza virus, which is a singlestranded, negative-sense RNA virus of the Paramyxoviridae family and Rubulavirus genus, and causes bronchiolitis and pneumonia in humans. 